\title{
Increased interleukin 8 expression in the colon mucosa of patients with inflammatory bowel disease
}

\author{
R Daig, T Andus, E Aschenbrenner, W Falk, J Schölmerich, V Gross
}

\begin{abstract}
To test whether there is a difference in the expression of interleukin 8 (IL8) between Crohn's disease and ulcerative colitis and to determine the main site of its synthesis this study analysed IL8 in mucosal biopsy specimens of patients with Crohn's disease and ulcerative colitis by enzyme linked immunosorbent assay (ELISA) and by in situ hybridisation. IL8 was measured by ELISA in 38 normal control patients, eight inflammatory control patients, 55 Crohn's disease biopsy specimens (26 patients), and 67 ulcerative colitis biopsy specimens (35 patients). IL8 mRNA was determined in samples by in situ hybridisation using a specific IL8 RNA probe. IL8 protein was significantly increased in macroscopically inflamed specimens of Crohn's disease (median $118 \mathrm{pg} / \mathrm{specimen,} \mathbf{p}<0.0001$ ), ulcerative colitis (median $140 \mathrm{pg} / \mathrm{speci-}$ men, $p<0.001$, and inflammatory controls (median $30 \mathrm{pg} / \mathrm{specimen,} \mathrm{p}=\mathbf{0} \cdot 010$ ) compared with normal controls (median 4 pg/specimen). IL8 was also increased in uninflamed specimens of Crohn's disease (median $46 \mathrm{pg} / \mathrm{specimen,} p<0.001$ ) but not of ulcerative colitis patients (median $9 \mathrm{pg} / \mathrm{specimen,} \mathrm{p}=0.3$ ). IL8 protein in the mucosa correlated significantly with macroscopic inflammation in Crohn's disease $(r=0.47, p<0.001)$ and in ulcerative colitis $(r=0.60, p<0.001)$. IL8 mRNA was detected by in situ hybridisation in 31 of 55 biopsy specimens (56\%) of Crohn's disease patients, in 38 of 67 specimens of ulcerative colitis patients $(57 \%)$, in five of eight inflammatory controls (63\%) and in five of 38 normal controls (13\%). Mucosal IL8 mRNA expression correlated with mucosal IL8 protein $(r=0.46, p<0.001)$. IL8 mRNA was only detected in inflammatory cells of the interstitium but not in mucosal epithelial cells. IL8 is produced mainly in the lamina propria of the colon in inflammatory bowel disease and correlates with mucosal inflammation.

(Gut 1996; 38: 216-222)
\end{abstract}

Keywords: interleukin 8, inflammatory bowel disease, mucosal immunology, in situ hybridisation, cytokines, chemokines.

Interleukin (IL8) is a member of the chemokine family. It is a major chemotactic and activating peptide for neutrophils. It activates the motile apparatus of neutrophils, induces a direct migration, the expression of surface adhesion molecules, the release of enzymes, and the production of reactive oxygen metabolites. ${ }^{1}$ IL8 can be produced by different cell types, for example, mononuclear phagocytes, ${ }^{2-4}$ endothelial cells, ${ }^{5}$ fibroblasts, ${ }^{6}$ and various epithelial cell types. ${ }^{78}$ The expression of the IL8 gene in various cell types may be enhanced by lipopolysaccharide, IL1, tumour necrosis factor $\alpha$, phorbol esters and agents that increase the level of intracellular cAMP. ${ }^{9}$

Recently, it has been shown that IL8 is synthesised by various colonic cancer cell lines like HT-29 cells or Caco- 2 cells. ${ }^{10-12}$ Evidence has also been provided that isolated normal intestinal epithelial cells may synthesise IL8. ${ }^{10}$

An increased synthesis of IL8 has been described in the mucosa of patients with inflammatory bowel disease. Whereas Mahida and coworkers ${ }^{13}$ found enhanced mucosal tissue concentrations of IL8 essentially only in patients with ulcerative colitis but not in patients with Crohn's disease Izzo et al ${ }^{14}$ detected increased concentrations of IL8 also in the colonic mucosa from patients with Crohn's disease. As these studies determined IL8 in tissue homogenates no information is available concerning the cell types responsible for the increased IL8 synthesis in inflammatory bowel disease. Thus, the question whether intestinal epithelial cells contribute to the synthesis of IL8 in vivo during chronic intestinal inflammation is uncertain. We therefore analysed the expression of IL8 in colonic mucosal biopsy specimens by ELISA (IL8 protein) and by in situ hybridisation (IL8 mRNA) to test whether there is a difference in the expression of IL8 between Crohn's disease and ulcerative colitis and to determine the main site of IL8 synthesis during these chronic inflammatory diseases.

\section{Methods}

\section{Patients}

The study was approved by the ethical committee of the University of Regensburg, Germany. Fifty five endoscopic biopsy specimens were obtained from the colon of 26 patients with Crohn's disease (eight patients with one specimen, 15 patients with two specimens, one patient with two specimens each from two different time points, one patient with two specimens from each of three colonoscopies, and one patient with one biopsy and with two specimens each from three additional colonoscopies). From 35 patients with
Dr V Gross, Depart

Internal Medicine I,

University of Regensburg

93042 Regen

Accepted for publication 24 July 1995 
ulcerative colitis 67 biopsy specimens were obtained (12 patients with one specimen, 16 patients with two specimens, one patient with two specimens from two different colonoscopies, two patients with two specimens each from two different time points, one patient with four specimens, and three patients with one specimen and two specimens from an additional colonoscopy). If multiple specimens were taken from one patient, they were taken from areas of different degrees of inflammation, if possible from inflamed and uninflamed areas (15 patients with ulcerative colitis, 12 patients with Crohn's disease). For comparison, normal control biopsy specimens $(n=38)$ were taken from 38 patients undergoing colonoscopy for various reasons (for example, cancer screening, polypectomy). Inflammatory control specimens $(n=8)$ were taken from eight patients with diverticulitis or infectious colitis. The mean age of Crohn's disease patients (10 male, 16 female) was 30 years (range 17-43), 20 were taking corticosteroids, nine 5-ASA, seven sulphasalazine, two azathioprine (drug combinations possible). The mean age of ulcerative colitis patients (22 male, 13 female) was 35 years (range 16-70), 22 were taking corticosteroids, 20 5-ASA, four sulphasalazine, one azathioprine (drug combinations possible).

\section{Biopsy specimens}

The degree of inflammation at the biopsy site was assessed macroscopically: $0=$ normal mucosa, $1=$ low degree of inflammation (increased granularity and friability of mucosa in ulcerative colitis, single small aphthous lesions in Crohn's disease), $2=$ moderate inflammation (mucous membranes, spontaneous bleeding and small ulcers in ulcerative colitis, multiple aphthous lesions, and small ulcers in Crohn's disease), $3=$ severe inflammation (large ulcers in ulcerative colitis, large ulcerous lesions in Crohn's disease). In Crohn's disease, the macroscopic scores were distributed as follows: $0(n=15), 1(n=14), 2$ $(n=7), 3(n=19)$, in ulcerative colitis as

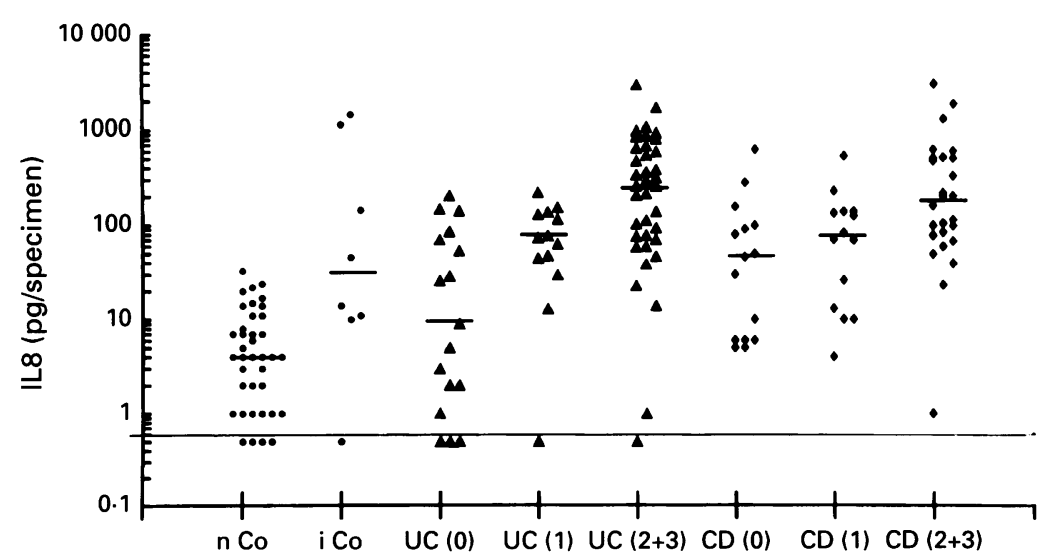

Figure 1: IL8 protein in colonic mucosa. IL8 protein was determined in 38 normal control specimens ( $n \mathrm{Co}$ ), in eight inflammatory controls ( $i \mathrm{Co}$ ), in 55 Crohn's disease specimens (CD), and in 67 ulcerative colitis specimens (UC). Inflammation was assessed macroscopically $(0=$ normal mucosa, $1=$ low degree of inflammation, $2=$ moderate inflammation, $3=$ severe inflammation). IL 8 protein was determined by ELISA in the supernatants from homogenates of specimens after freezing and thawing the specimens supernatants from homogenates of specimens after freezing and thawing the specimens
twice. The medians are shown by bars. The thin line represented the detection limit at $0.6 \mathrm{pg}$ IL8/specimen. follows: $0 \quad(n=17), 1 \quad(n=13), 2(n=7), 3$ $(n=20)$. Specimens for histological assessments $(0=$ normal, $1=$ low degree of inflammation, 2 =moderate inflammation, $3=$ severe inflammation), for the determination of IL8 protein by ELISA and for the determination of IL8 mRNA by in situ hybridisation were taken from essentially the same regions. Histological assessment of the degree of inflammation correlated well with the macroscopic assessment in Crohn's disease $(r=0.66, \mathrm{p}<0.001)$ and in ulcerative colitis $(r=0.70, \mathrm{p}<0.001)$.

The mean (SD) weight of samples was 7.9 $(2 \cdot 3) \mathrm{mg}$ with no difference between samples taken from control patients $(8 \cdot 1(2 \cdot 2) \mathrm{mg})$, Crohn's disease patients $(7.6(2.4) \mathrm{mg})$ or ulcerative colitis patients $(8 \cdot 1(2 \cdot 1) \mathrm{mg})$. Specimens for IL8 protein determination were washed in phosphate buffered saline (PBS) and then immediately frozen at $-20^{\circ} \mathrm{C}$. Biopsy specimens for IL8 mRNA detection were taken up in freshly prepared $4 \%$ paraformaldehyde. After prefixation overnight they were taken up in OCT-compound (Tissue-Tek Miles, Elkhart, IN, USA) and frozen at $-20^{\circ} \mathrm{C}$.

\section{Determination of IL8 protein}

Specimens were homogenised by two cycles of freezing and thawing in $200 \mu \mathrm{l}$ PBS, $\mathrm{pH} 7 \cdot 2$ in the presence of proteinase inhibitors (leupeptin $10 \mu \mathrm{g} / \mathrm{ml}$, pepstatin $10 \mu \mathrm{g} / \mathrm{ml}$, aprotinin 1 $\mu \mathrm{g} / \mathrm{ml}$, EDTA $0.5 \mathrm{mg} / \mathrm{ml}$ ). Insoluble material was spun down at $18000 \mathrm{~g}$ for five minutes. An aliquot of the soluble supernatant was used for the IL8 determination by ELISA ( $R$ \& D Systems, Minneapolis, MN), and another aliquot for the determination of total protein by BCA protein assay (Sigma, Deisenhofen, Germany).

\section{Hybridisation probes}

The IL8 probe consisted of a 244 base pair fragment subcloned into the EcoRI/PstI site of the polylinker of the transcription vector pBS $(+)$. The subcloning was confirmed by dideoxysequencing using T7-DNA polymerase (USB, Cleveland, Ohio, USA). For the in situ hybridisation experiments ${ }^{35} \mathrm{~S}$-UTP labelled antisense or sense riboprobes were prepared by in vitro transcription using $\mathrm{T} 7$ or T3-RNA polymerase (Promega, Madison, WI, USA), respectively.

\section{In situ hybridisation}

Freeze sections were performed using a Jung Frigocut $2800 \mathrm{E}$ Cryotom. Five $\mu \mathrm{m}$ slices were mounted on p-L-lysine coated slides. The sections were refixed in freshly prepared $4 \%$ paraformaldehyde in PBS ( $\mathrm{pH} 7 \cdot 2$ ) for 15 minutes at $4^{\circ} \mathrm{C}$ and then washed by dipping in DEPC treated water. Hybridisation was performed as described. ${ }^{15}$ In brief, the sections were rehydrated in $2 \times \mathrm{SSC}$, acetylated in $0.1 \mathrm{M}$ triethanolamine with $0.25 \%$ acetic anhydride and incubated in glycine buffer $(0 \cdot 1 \mathrm{M}$ glycine, $0.2 \mathrm{M}$ TRIS- $\mathrm{HCl}, \mathrm{pH} 7 \cdot 4)$. They were then covered with prehybridisation 

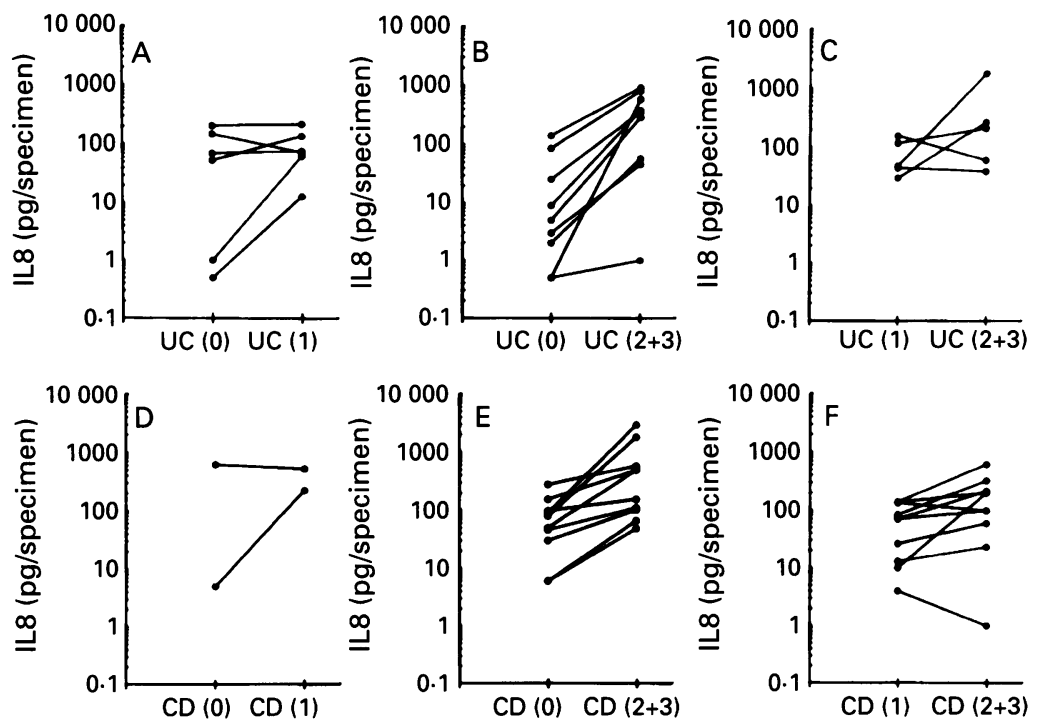

Figure 2: Comparison between intraindividual mucosal IL8 concentrations at sites with different degrees of inflammation. IL8 protein was determined in the mucosa of patients with ulcerative colitis (UC) or Crohn's disease (CD). Inflammation was assessed macroscopically ( $0=$ normal mucosa, $1=$ low degree of inflammation, $2=$ moderate inflammation, $3=$ severe inflammation). The figure represents the paired values of those patients permitting a comparison between uninflamed and inflamed areas $(0 \mathrm{v} 1$ or $0 \mathrm{v} 2$ or 3) or between areas of low degree of inflammation and higher degrees of inflammation (1 1 2 or 3$)$.

\section{Measurement and statistics}

The number of IL8 expressing cells in the lamina propria and the amount of grains per positive cell were counted in three randomly selected microscopic fields at a final magnification of $400 \times\left(67.5 \mathrm{~mm}^{2}\right)$. All the in situ hybridisation experiments were performed with a sense probe as control and evaluated in a blinded fashion. IL8 expression was classified as: $0=$ no expression; $1=$ low expression $(\leqslant 5$ positive cells/field with maximal 15 grains per cell); $2=$ moderate expression (6-14 positive cells/field with maximal 30 grains per cell); $3=$ strong expression $(\geqslant 15$ positive cells/field with more than 30 grains per cell).

The statistical analyses were performed by Student's $t$ test for parametric data and by the Kruskal-Wallis H test, the Mann-Whitney, and the Spearman rank test as appropriate for nonparametric data. Differences were considered significant with $\mathrm{p}<0 \cdot 05$.

\section{Results}

\section{Determination of IL 8 protein}

IL8 protein was determined in 38 normal control biopsy specimens and in eight inflammatory control specimens, in 55 specimens from Crohn's disease patients and in 67 specimens from ulcerative colitis patients. Before single groups were compared multiple group comparison (Kruskal-Wallis $\mathrm{H}$ test, because the data were not normally distributed) was done to test for significant differences between different groups $(p<0.0001$ for IL8/specimen or IL8/mg protein). In normal control samples only low amounts of IL8 protein could be detected (median $4 \mathrm{pg} / \mathrm{specimen}$, interquartile range $1 \cdot 2-11 \cdot 0 \mathrm{pg} /$ specimen). The IL8 protein concentration increased in the case of inflammatory controls (median 30 $\mathrm{pg} / \mathrm{specimen}$, interquartile range 10.3-901). IL8 protein expression in uninflamed mucosa of patients with ulcerative colitis was comparable to that of uninflamed control mucosa (median $9 \mathrm{pg} / \mathrm{biopsy}$, interquartile range $1 \cdot 4-79 \cdot 2 \mathrm{pg} / \mathrm{specimen}$ ). Significantly increased $(p<0.001)$ amounts of IL8 protein were, however, detected in macroscopically inflamed specimens of patients with ulcerative colitis (median $140 \mathrm{pg} /$ specimens, interquartile range $59.7-496 \mathrm{pg} / \mathrm{specimen})$. In patients with Crohn's disease increased concentrations of IL8 protein were found in inflamed (118 $\mathrm{pg} / \mathrm{specimens}$, interquartile range $61 \cdot 1-432$ $\mathrm{pg} / \mathrm{specimens,} \mathrm{p}<0.001$ ) as well as in uninflamed specimens (median $46 \mathrm{pg} / \mathrm{specimen}$, interquartile range $6.0-99.3 \mathrm{pg} / \mathrm{specimen}$, and counterstained with Giemsa stain.

Protein content of mucosal biopsy specimens and ratios between IL8 and total protein

\begin{tabular}{|c|c|c|c|c|}
\hline $\begin{array}{l}\text { Disease and } \\
\text { macroscopic inflammation }\end{array}$ & $\begin{array}{l}\text { Total protein }(\mathrm{mg}) / \\
\text { specimen median } \\
(95 \% \text { confidence intervals) }\end{array}$ & $\begin{array}{l}\text { p Value } \\
\text { (v control) }\end{array}$ & $\begin{array}{l}\text { IL8 protein }(\mathrm{pg}) / \\
\text { total protein }(\mathrm{mg}) \text { median } \\
\text { (interquartile range) }\end{array}$ & $\begin{array}{l}\text { p Value } \\
\text { (v control) }\end{array}$ \\
\hline $\begin{array}{l}\text { Uninflamed control }(n=31) \\
\text { Inflamed control }(n=7) \\
\text { Inactive } C D(n=11) \\
\text { Active } C D(n=38) \\
\text { Inactive } U C(n=15) \\
\text { Active UC }(n=37)\end{array}$ & $\begin{array}{l}0.088(0.072 \text { to } 0.103) \\
0 \cdot 144(0.073 \text { to } 0.216) \\
0 \cdot 110(0.066 \text { to } 0 \cdot 154) \\
0 \cdot 150(0.114 \text { to } 0.187) \\
0 \cdot 100(0.078 \text { to } 0 \cdot 122) \\
0.113(0.092 \text { to } 0.133)\end{array}$ & $\begin{array}{l}0 \\
\text { NS } \\
\text { NS } \\
0 \cdot 018 \\
\text { NS } \\
\text { NS }\end{array}$ & $\begin{array}{c}79 \cdot 7(14-115) \\
229(106-4670) \\
495(64-1360) \\
820(383-2820) \\
248(17-841) \\
1540(672-4400)\end{array}$ & $\begin{array}{l}0 \\
0.003 \\
<0.001 \\
<0.001 \\
\text { NS } \\
<0.001\end{array}$ \\
\hline
\end{tabular}

$\mathrm{NS}=$ no significance, $\mathrm{CD}=\mathrm{Crohn}$ 's disease, $\mathrm{UC}=$ ulcerative colitis. 


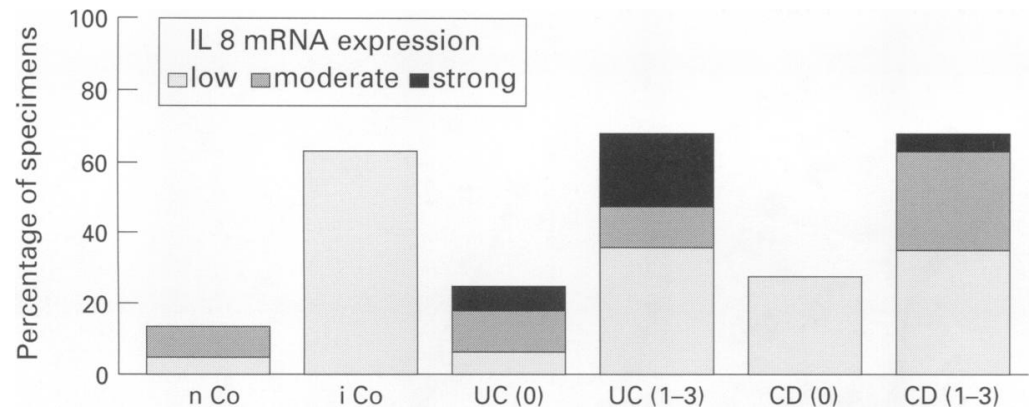

Figure 3: Semiquantitative determination of IL8 $\mathrm{mRNA}$ expression in colonic mucosa by in situ hybridisation. IL $8 \mathrm{mRNA}$ was localised by in situ hybridisation using ${ }^{35} S-U T P$ labelled IL 8 antisense RNA as described in methods. Thirty eight normal control specimens ( $n \mathrm{Co})$, eight inflammatory control specimens ( $i \mathrm{Co}), 55 \mathrm{Crohn}$ 's disease specimens $(C D)$, and 67 ulcerative colitis specimens (UC) were analysed. Inflammation was assessed macroscopically $(0=$ normal mucosa, $1=$ low degree of inflammation, $2=$ moderate inflammation, $3=$ severe inflammation). The figure shows the percentage of specimens in each group expressing IL8.

$\mathrm{p}=0.001)$. Figure 1 shows the individual data.

When mucosal IL8 concentrations were compared intraindividually between sites with different degrees of inflammation (Fig 2) higher IL8 concentrations were found at sites with a higher degree of inflammation $(p=0.001$ for ulcerative colitis, $p=0.0006$ for Crohn's disease, using the paired Wilcoxon test).

To exclude the possibility that the observed differences result from the different protein content of the specimens caused by different numbers of infiltrating inflammatory cells, we determined the protein content of seven inflamed and 31 normal control specimens, 38 inflamed and 11 uninflamed specimens of patients with Crohn's disease, and of 37 inflamed and 15 uninflamed specimens of patients with ulcerative colitis and calculated the ratio between IL8 protein and total protein. As the Table shows, the differences remained similar for the data normalised to the protein content of the specimens, although the total protein content was higher in the inflamed samples.

There was a significant positive correlation between the amount of IL8 protein in the mucosa and the endoscopic inflammation score in patients with Crohn's disease (Spearman rank: $r=0.47, \mathrm{p}<0.001$ ), and in

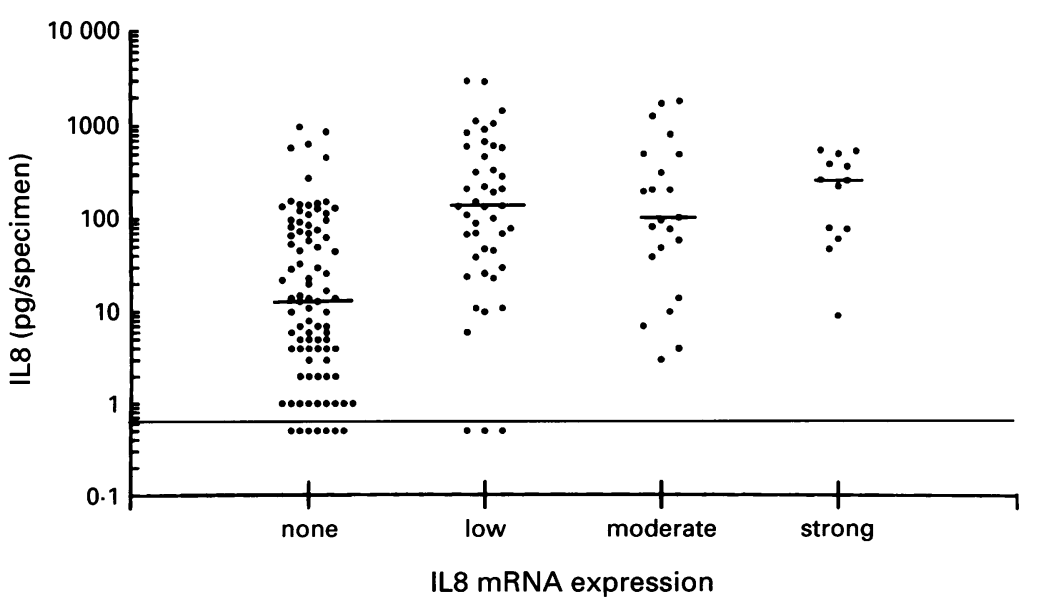

Figure 4: Correlation between IL8 $m R N A$ expression and IL8 protein in colonic biopsy specimens. IL $8 \mathrm{mRNA}$ was detected by in situ hybridisation and IL8 protein was determined by ELISA. The detection limit of IL 8 protein measurement is shown by a thin line at $0.6 \mathrm{pg}$ IL8/specimen. The medians are shown by bars. ulcerative colitis $(r=0 \cdot 58, \mathrm{p}<0 \cdot 001)$. IL8 concentrations were not significantly higher in the inflamed mucosa of ulcerative colitis patients than in the inflamed mucosa of patients with Crohn's disease.

To assess the effect of treatment, we compared IL8 protein values of patients with active Crohn's disease and active ulcerative colitis receiving treatment with patients not receiving treatment. Patients with active Crohn's disease receiving treatment $(n=19)$ had similar IL8 protein values (median: $134 \mathrm{pg} / \mathrm{specimen}$, interquartile range: $27 \cdot 7-503$ ) as patients not receiving treatment $(\mathrm{n}=5)$ (median: 348 $\mathrm{pg} /$ specimen, $127-587, \mathrm{p}=0 \cdot 32$ ). Also patients with active ulcerative colitis receiving treatment $(n=28)$ had similar IL8 protein values (median: $333 \mathrm{pg} /$ specimen, interquartile range: $28 \cdot 6-640)$ as patients without treatment $(n=6)$ (median $262 \mathrm{pg} /$ specimen, 29.6-754, $\mathrm{p}=0.66)$.

\section{In situ hybridisation}

Cells expressing IL 8 could be detected by in situ hybridisation using a specific ${ }^{35} \mathrm{~S}-\mathrm{UTP}$ labelled IL8 antisense RNA probe in five of 38 normal controls $(13 \%)$ and five of eight inflammatory controls $(63 \%)$, in 31 of 55 specimens of Crohn's disease patients $(56 \%)$, and in 38 of 67 specimens of ulcerative colitis patients $(57 \%)$ (Fig 3). When IL8 mRNA expression was determined semiquantitatively the IL8 mRNA expression in normal biopsy specimens was mainly low $(5 \%)$ or moderate $(8 \%)$. Also IL8 expression in inflammatory controls was mainly low (63\%). In Crohn's disease, however, 32\% showed a low, $20 \%$ a moderate, and $4 \%$ a strong expression of IL8 mRNA. The corresponding values in ulcerative colitis specimens were $29 \%$ for low expression, $12 \%$ for moderate expression, and $16 \%$ for strong expression.

When mucosal IL8 mRNA expression was correlated with mucosal IL8 protein concentrations a statistically significant correlation was found $(r=0.46, p<0.001)$ (Fig 4). There was also a statistically significant correlation between the macroscopic score of inflammation and the amount of IL8 mRNA detected by in situ hybridisation $(r=0.51, \mathrm{p}<0.001)$.

The analysis of the cell types expressing IL8 mRNA showed that in none of the 168 specimens IL8 mRNA was expressed in detectable amounts in mucosal epithelial cells. Cells positive for IL8 mRNA were always located in the mucosa, presumably representing infiltrating inflammatory cells. Figure 5 shows examples for the detection of IL8 mRNA in a normal control patient as well as in a patient with Crohn's disease with strong expression of IL8 $\mathrm{mRNA}$, and in a patient with ulcerative colitis, also showing strong expression of IL8 mRNA. In the case of the two inflammatory bowel disease patients IL8 sense RNA probes were used as specificity controls.

\section{Discussion}

The aetiology of Crohn's disease and ulcerative colitis is still unknown. It is, however, 

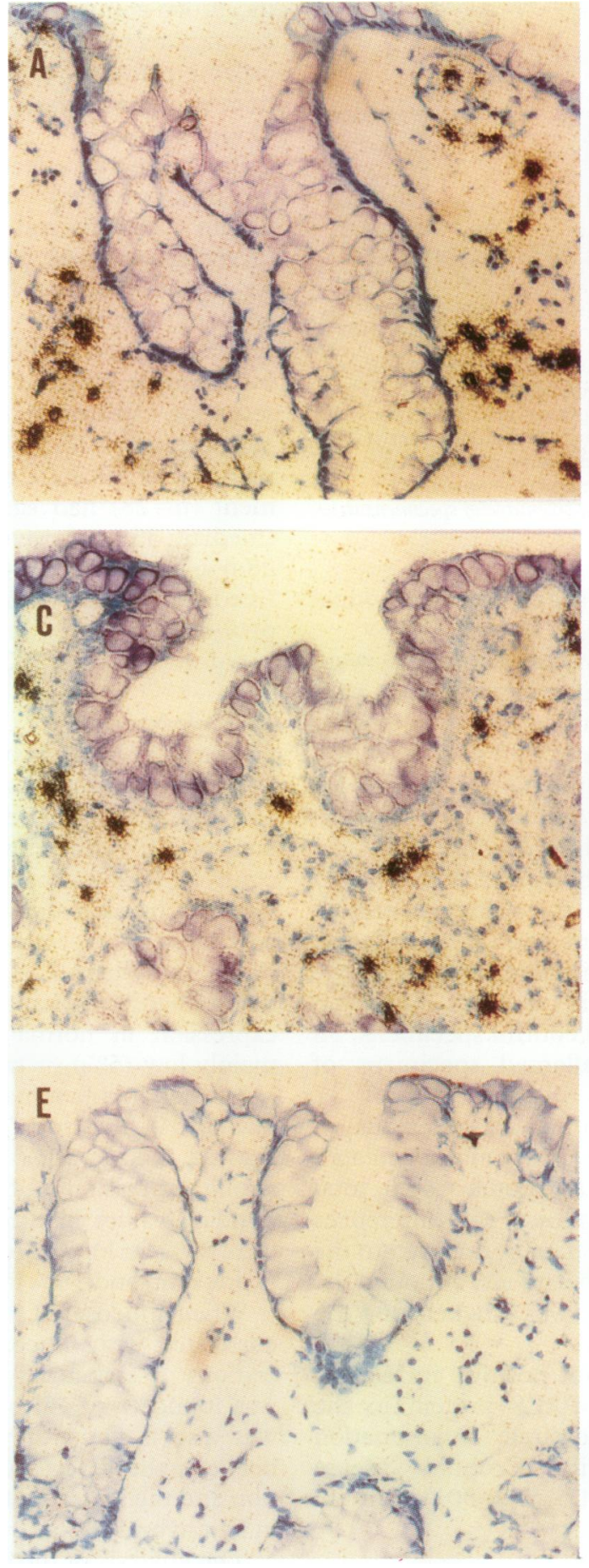

generally assumed that disturbances of the intestinal immune system are at least a prerequisite for the development of these diseases. Among the mediators orchestrating the immune system cytokines play an essential part. Recent data suggest that an imbalance of the intestinal immune system with a shift towards proinflammatory mediators is a characteristic feature of inflammatory bowel diseases. ${ }^{16-27}$ Among the proinflammatory cytokines IL8 together with IL1 and tumour necrosis factor play an important part. IL8 belongs to the chemokine family and is an effective neutrophil activating peptide. ${ }^{1}$ Our results show that the synthesis of IL8 is upregulated in the inflamed colonic mucosa of patients with Crohn's disease as well as in patients with ulcerative colitis.
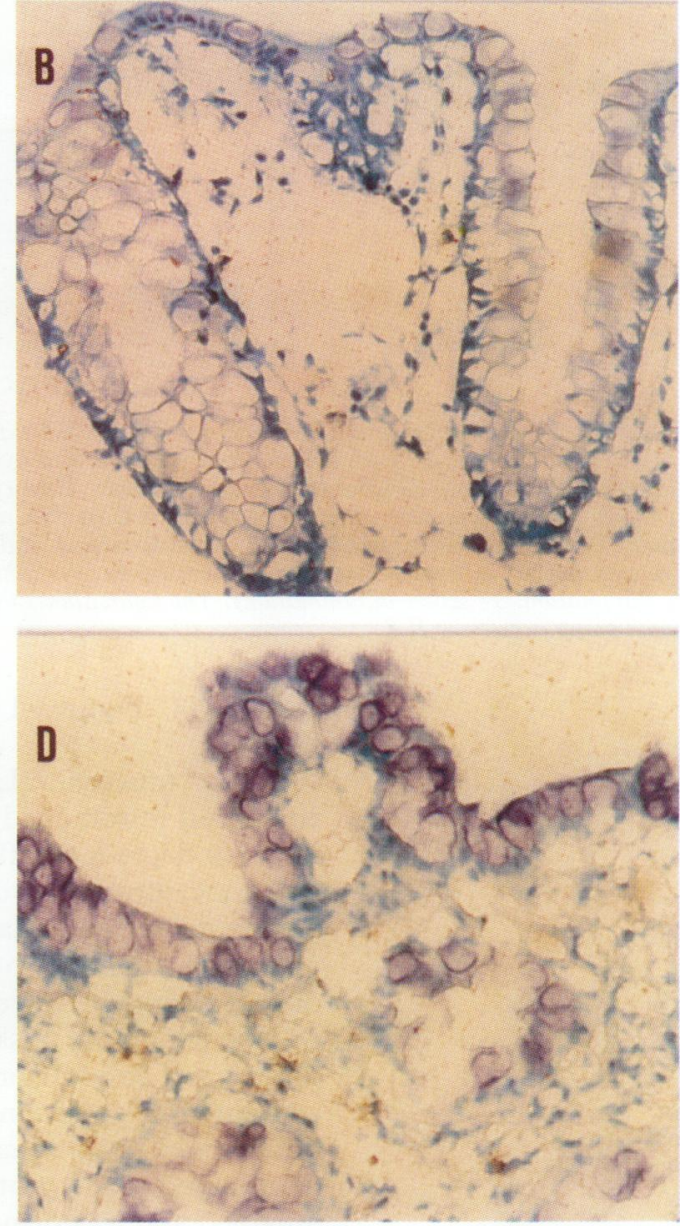

Figure 5: Detection of IL $8 \mathrm{mRNA}$ in colonic mucosa by in situ hybridisation. IL $8 \mathrm{mRNA}$ was located in colonic

biopsy specimens by in situ hybridisation using $a^{35} S$-UTPlabelled IL 8 RNA probe as described in methods (original magnification $\times 200$ ). A: Crohn's disease (antisense probe); B: Crohn's disease (sense probe); C: ulcerative colitis (antisense probe); D: ulcerative colitis (sense probe); E: control (antisense probe).

It has previously been described that IL8 is mainly increased in active ulcerative colitis but not in Crohn's disease. ${ }^{13}$ The different regulation of IL8 in Crohn's disease and in ulcerative colitis would have been of great pathophysiological interest, as both diseases show some differences in their histopathological appearance. While infiltration with neutrophils and the formation of crypt abscesses is a hallmark of ulcerative colitis, Crohn's disease is characterised by granulomas. ${ }^{28} 29$ In the case of IL6 it has been shown that there is a difference between Crohn's disease and ulcerative colitis. ${ }^{24} 25$ Its circulatory concentrations were more increased in patients with Crohn's disease than in patients with ulcerative colitis suggesting that there is a persisting stimulation of IL6 producing 
cells in Crohn's disease but not in ulcerative colitis. ${ }^{25}$

We found that IL8 concentrations in the inflamed mucosa are similar for Crohn's disease and ulcerative colitis. IL8 expression is increased independent of the cause of the inflammation including also the inflammatory controls. The apparent discrepancy between our findings and those of Mahida ${ }^{13}$ might be explained by the fact that Crohn's disease is a discontinuous disease and IL8 concentrations might vary between inflamed and uninflamed areas that are close together. Although uninflamed mucosa of patients with Crohn's disease contains increased amounts of IL8 when compared with normal mucosa of control persons, the IL8 content is further increased in moderately or severely inflamed mucosa of patients with either Crohn's disease or ulcerative colitis. Our data are, on the other hand, in accordance with the findings of Izzo et $a l^{14}$ who also detected substantially increased mucosal IL8 concentrations in the colon of patients with Crohn's disease. Thus, mucosal IL8 expression does not permit differentiation between Crohn's disease and ulcerative colitis. Two recent publications ${ }^{30} 31$ support this view. There is, however, one important difference between Crohn's disease and ulcerative colitis - that is, IL8 concentrations are also increased in uninflamed mucosa of patients with Crohn's disease but not in uninflamed mucosa of patients with ulcerative colitis. This may show that there is a continuous stimulation of the intestinal immune system in Crohn's disease while this stimulation is restricted to grossly inflamed areas in ulcerative colitis. This upregulation of the intestinal immune system might be a general feature of Crohn's disease. On a systemic level it may be reflected by increased IL6 concentrations in patients with Crohn's disease even when they are clinically in remission. ${ }^{25}$ This hypothesis is further supported by data showing increased ILl concentrations in macroscopically uninflamed mucosa of patients with Crohn's disease (Andus et al, unpublished results). The fact that drugs had no influence on IL8 protein may be caused by the fact, that if they inhibit IL8 they also inhibit inflammation, which in turn leads to a downgrading of the specimens from inflamed to uninflamed. This shows that the IL8 content of the specimens is closely related to the extent of inflammation.

Thus far, the site of synthesis of IL8 in inflammatory bowel diseases is still uncertain. As various colonic epithelial cell lines as well as isolated intestinal epithelial cells have been shown to produce IL $8,{ }^{10-12}$ the hypothesis had to be tested whether colonic epithelial cells contribute to the synthesis of IL8. Another open question was whether the sites of IL8 synthesis are different in Crohn's disease and in ulcerative colitis. Our study showed that IL8 positive cells are only found in the interstitium but never in the epithelial layer of the colonic mucosa. The distribution of IL8 producing cells resembled that of IL1 or tumour necrosis factor producing cells as shown by Capello et al. ${ }^{32}$ Obviously, infiltrating inflammatory cells are the main producers of the proinflammatory cytokines. Although in situ hybridisation is a very sensitive technique, we cannot totally exclude that small amounts of IL8 may be produced by colonic epithelial cells. This has recently been claimed by Izutani et al ${ }^{33}$ who showed IL8 mRNA in isolated intestinal epithelial cells from inflammatory bowel disease mucosa using a quantitative polymerase chain reaction assay. When interpreting these data ${ }^{33}$ two important points have to be considered: (a) only a few contaminating macrophages may contribute considerable amounts of IL8 mRNA, (b) the isolation procedure may induce IL8 mRNA in epithelial cells, which otherwise would not express it. As a result of our experiments we assume that during chronic inflammatory conditions such as Crohn's disease or ulcerative colitis colonic epithelial cells do not produce considerable amounts of IL8 mRNA.

In conclusion, it was found that IL8 is produced in the colonic lamina propria of patients with inflammatory bowel disease. There is no difference in IL8 protein concentrations between inflamed mucosa of patients with Crohn's disease or ulcerative colitis. IL8 does thus not permit the differentiation between these two diseases entities. Mucosal IL8 protein and IL8 mRNA concentrations are correlated with the degree of inflammation. IL8 mRNA is strongly expressed by intestinal inflammatory cells but not by intestinal epithelial cells suggesting that virtually all IL8 is produced by interstitial inflammatory cells.

Supported by the Deutsche Forschungsgemeinschaft (Heisenberg Stipendium to VG, and grant Gr 740/5-1, and the Sander Stiftung). This work was published in abstract form (Gastroenterology 1994; 106: A669).

1 Baggiolini M, Walz A, Kunkel SL. Neutrophil-activating peptide-1/interleukin-8, a novel cytokine that activates neutrophils. F Clin Invest 1989; 84: 1045-9.

2 Yoshimura T, Matsushima K, Tanaka S, Robinson EA Appella E, Oppenheim JJ, et al. Purification of a human monocyte-derived neutrophil chemotactic factor that has monocyte-derived neutrophil chemotactic factor that has
peptide sequence similarity to other host defense peptide sequence similarity to other host defense
cytokines. Proc Natl Acad Sci USA 1987; 84: 9233-7.

3 Schroeder JM, Mrowietz U, Morita E, Christophers E. Purification and partial biochemical characterization of a human monocyte-activating peptide that lacks interleukin-1 activity. $\mathcal{F}$ Immunol 1987; 139: 3474-83.

4 Peveri P, Walz A, Dewald B, Baggiolini $M$. A novel neutrophil-activating factor produced by human nuclear phagocytes. F Exp Med 1988; 167: 1547-59.

5 Schroeder JM, Christophers E. Secretion of novel and homologous neutrophil-activating peptides by LPS-stimhomologous neutrophil-activating peptides by LPS-stim244-51.

6 Strieter RM, Phan SH, Showell HJ, Remick DG, Lynch JP, Genord $M$, et al. Monokine-induced neutrophil chemotactic factor gene expression in human fibroblasts. $\mathcal{F ~ B i o}$ Chem 1989; 264: 10621-6.

7 Elner VM, Strieter RM, Elner SG, Baggiolini M, Linley I, Kunkel SL. Neutrophil chemotactic factor (IL-8) gene expression by cytokine-treated retinal pigment epithelia cells. Am F Pathol 1990; 136: 745-50.

8 Schmouder RL, Strieter RM, Wiggrins RC, Chensue SW, Kunkel SL. In vitro and in vivo interleukin-8 production in human renal cortical epithelia. Kidney Int 1992; 41: 191-8.

9 Mukaida N, Shiroo M, Matsushima K. Genomic structure of the human monocyte-derived neutrophil chemotactic of the human monocyte-derived neutrophil

10 Eckmann L, Jung HC, Schürer-Maly C, Panja A, Morzycka-Wroblewska E, Kagnoff MF. Differential cytokine expression by human intestinal epithelial cell cytokine expression by human intestinal epithelial cell lines: regulated expression of interleukin-8. Gastroenterology 1993; 105: 1698-97.

11 Nguyen HC, Ohno Y, Reinecker HC, Furth EE, MacDermott RP, Rombeau JC. CaCo-2 cells synthesize and secrete increased amounts of interleukin-8 after stimulation by PMA, IL-1, and IL-1. Gastroenterology 1993; 104: A754. 
12 Gross V, Andus T, Daig R, Aschenbrenner L, Falk W, Schölmerich J. Protein tyrosine kinase activation is required for induction of IL-8 by IL-1 or TNF in an intestinal epithelial cell line (HT-29). Gastroenterology 1994; 106: A694.

13 Mahida YR, Ceska M, Effenberger F, Kurlak L, Lindley I, Hawkey CJ. Enhanced synthesis of neutrophil-activating peptide-I/interleukin-8 in active ulcerative colitis. Clin Sci 1992; 82: 2173-5.

14 Izzo RS, Witkon K, Chen AI, Hadjiyane C, Weinstein MI, Pellecchia C. Neutrophil-activating peptide (interleukin8 ) in colonic mucosa from patients with Crohn's disease. Scand $\mathcal{F}$ Gastroenterol 1993; 28: 296-300.

15 Gross V, Villiger PM, Zhang B, Lotz M. Retinoic acid inhibits interleukin-1-induced cytokine synthesis in human monocytes. I Leukoc Biol 1993; 54: 125-32. 16 Sartor RB. Pathogenetic and clinical relevance of cytokines
in inflammatory bowel disease. Immunol Res 1991; 27: 897-906.

17 Schreiber S, Raedler A, Stenson WF, MacDermott RP. The role of the mucosal immune system in inflammatory bowel disease. Gastroenterol Clin North Am 1992; 21: 451-502.

18 Cominelli R, Nast CC, Clark BD, Schindler R, Lierena R, Eysselein VE, et al. Interleukin-1 (IL-1) gene expression, Eysselein VE, et al. Interleukin-1 (IL-1) gene expression, synthesis, and effect of specific IL-1 receptor blockade in rabbits im $972-80$.

19 Brynskov J, Tvede N, Andersen CB, Vilien M. Increased concentrations of interleukin-1, interleukin-2, and soluble interleukin-2 receptor in endoscopical mucosal biopsy specimens with active inflammatory bowel disease. $G u$ 1992; 33: 55-8

20 Issacs K, Sartor RB, Haskill JS. Cytokine messenger RNA profiles in inflammatory bowel disease mucosa detected by polymerase chain reaction amplification Gastroenterology 1992; 103: 1587-95.

21 Cominelli F, Nast CC, Duchini A, Lee M. Recombinan interleukin-1 receptor antagonist blocks the proinflammatory activity of endogenous interleukin-1 in rabbit immune colitis. Gastroenterology 1992; 103: 65-71.

22 Pullman WE, Elsbury S, Kobayashi M, Hapel AJ, Doe WF. Enhanced mucosal cytokine production in inflammatory bowel disease. Gastroenterology 1992; 102: 529-37.
23 Mullin GE, Lazenby AJ, Harris ML, Bayless TM, James SP. Increased interleukin-2 messenger RNA in the intestinal mucosal lesions of Crohn's disease but not ulcerative colitis. Gastroenterology 1992; 102: 1620-50.

24 Mahida YR, Kurlac L, Gallagher A, Hawkey CJ. High circulating concentrations of interleukin-6 in active Crohn's disease but not ulcerative colitis. Gut 1991; 32: 1531-4

25 Gross V, Andus T, Caesar I, Roth M, Schölmerich J. Evidence for continuous stimulation of interleukin-6 Evidence for continuous stimulation of interleukin-6 production.

26 Mitsuyama K, Sasaki E, Toyonaga A, Ikeda H, Tsuruta O, Irie $\mathrm{A}$, et al. Colonic mucosal interleukin-6 in inflammatory bowel disease. Digestion 1991; 50: 104-11.

27 Braegger CP, Nicholis S, Murch SH, Stephens S, MacDonald TT. Tumor necrosis factor- $\alpha$ in stool as a marker of intestinal inflammation. Lancet 1992; 339: 89-91.

28 Nixon JB, Riddell RH. Histopathology of ulcerative colitis. In: Allan RN, Keighley MRB, Alexander-Williams J, Hawkins CF, eds. Inflammatory bowel diseases. 2nd ed. Edinburgh: Churchill Livingstone, 1990: 246-62.

29 Thompson H. Histopathology of Crohn's disease. In: Allan RN, Keighley MRB, Alexander-Williams J, Hawkins CF, eds. Inflammatory bowel disease. 2nd ed. Edinburgh: eds. Inflammatory bowel disease. 2n

30 Mitsuyama K, Toyonaga A, Sasaki E, Watanabe K, Tateish $\mathrm{H}$, Nishiyama $\mathrm{T}$, et al. IL-8 as an important chemoattractant for neutrophils in ulcerative colitis and Crohn's disease. Clin Exp Immunol 1994; 96: 432-6.

31 Mazzucchelli L, Hauser C, Zgraggen K, Wagner H, Hess M, Laissue JA, et al. Expression of interleukin-8 gene in inflammatory bowel disease is related to the histological grade of active inflammation. Am 7 Pathol 1994; 144: 997-1007.

32 Capello $M$, Keshav S, Prince C, Jewell DP, Gordon S. Detection of mRNAs for macrophage products in inflammatory bowel disease by in situ hybridisation. Gut 1992; 33: $1214-9$.

33 Izutani R, Loh EY, Reinecker H-C, Ohno Y, Fusunyan RD, Lichtenstein GR, et al. Increased expression of interleukin-8 mRNA in ulcerative colitis and Crohn's disease mucosa and epithelial cells. Inflammatory Bowel Diseases 1995; 1: 37-47. 